\title{
The Routine Examination for Antibiotics Produced by Moulds
}

\author{
By N. G. HEATLEY AND FLORA J. PHILPOT \\ The Sir William Dunn School of Pathology, University of Oxford
}

\begin{abstract}
SUMMARY: From the existing methods for identifying common antibiotics it is possible to select tests for recognizing one or more of fourteen known antibiotics in crude culture medium. These tests, given in tabular form, are: (1) stability at $\mathrm{pH}$ 2.0 and $9.5 ;$ (2) ether-water partition at $\mathrm{pH} \mathrm{2.0,6 \cdot 0-7 \cdot 0}$ and 9.0 ; and (3) relative activity towards specified strains of Staphylococcus aureus and Bacterium coli. Further tests depend on destruction of penicillin by penicillinase, colour reactions, and volatility of aspergillic acid in steam. For final confirmation, isolation of the antibiotic may be necessary.
\end{abstract}

Several hundreds of moulds have been reported (Wilkins \& Harris, 1942, 1943, 1944 $a, 1944 b, 1944 c$; Furtado, 1944; Wiedling, 1944; Robbins, Hervey, Davidson, Ma \& Robbins, 1945; Wilkins, 1946; and others) to produce diffusible substances inhibiting Staph. aureus, Bact. coli, or other bacteria. In the Aspergilli and Penicillia it appears that the action is in many cases due to one or more of a few well-known antibiotics which it would be desirable to be able to recognize early in the investigation of the culture fluid of any new organism. There are three main ways in which this can be done:

(1) by comparing the antibacterial spectrum of the substance with that of known antibiotics;

(2) by the method proposed by Stansly (1946) in which the unknown material is tested against one or more organisms sensitive to each known antibiotic, and also against derived strains of the same organism(s) in which resistance to the antibiotic has been induced;

(3) by comparison of the chemical and bacteriological behaviour of the unknown with that of known antibiotics.

The first method, besides requiring several standard organisms, is not very specific and is not applicable to mixtures of antibiotics. With the second method, the demonstration of non-identity is unambiguous, but any result suggesting identity must for the present be accepted with some reservations, since insufficient is known at present about cross resistance. Thus Eisman, Marsh \& Mayer (1946) have shown that a staphylococcus made resistant to one of the three penicillins $\mathbf{F}, \mathrm{G}$ or $\mathrm{X}$ acquired resistance of the same order of magnitude to the others. We had observed the same result independently. Admittedly the ability to distinguish between different penicillins is a very severe test of any method; but the method also suffers from the defect that a large number of standard cultures are required, at least two for each antibiotic which is to be tested for.

The third method has been used by many workers. The scheme given below 
is merely one of many possible and though it is certainly not claimed to be the best, it may serve as a starting point for workers entering the field.

The information on which the scheme is based is partly drawn from the literature. Where the necessary information was lacking or was presented in an unsuitable form, it was obtained by direct experiment.

\section{Experimental}

In interpreting the results, it must always be borne in mind that more than one antibiotic may be produced in a culture, either simultaneously or successively. For this reason the time of harvesting of the culture fluid may be important.

As a preliminary it is perhaps worth ruling out the possibility that the inhibition is due to hydrogen peroxide, by incubating the medium with a trace of blood or of a catalase preparation. Destruction of the activity indicates hydrogen peroxide.

The following tests are then carried out:

(1) The stability of the inhibitor is determined at $100^{\circ}$ for $15 \mathrm{~min}$., and at $20^{\circ}$ for $30 \mathrm{~min}$, at $\mathrm{pH} \mathrm{2 \cdot 0}$ and $\mathrm{pH} 9 \cdot 5$. The samples must, of course, be neutralized before assay, and any changes in volume taken into account.

(col. 1 of the Table).

(2) Samples of the culture fluid are shaken with equal volumes of ether at

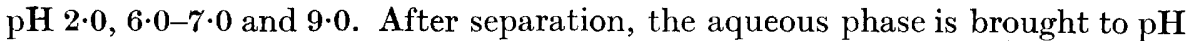
$5 \cdot 0-7 \cdot 0$ as quickly as possible, and a portion of the ether extract shaken with an equal volume of $\mathrm{m} / \mathbf{1 5}$-phosphate buffer of $\mathrm{pH} \mathbf{6 \cdot 8}$. The relative activity of the aqueous phase and the buffer extract of the ether is measured. Apparent loss of activity may be due to destruction at an unfavourable $\mathrm{pH}$ or the partition coefficient of the antibiotic being in favour of the ether at all $\mathrm{pH}$ values (col. 2 of the Table).

(3) Antibacterial specificity is examined. Only two strains of test bacterium have been used, namely, Staphylococcus aureus no. 6571 and Bacterium coli no. 86 of the National Collection of Type Cultures. The results recorded in column 6 of the Table were obtained with the cylinder-plate method (Heatley, 1944), the plates being surface-seeded with a 1:1000 dilution of a 16-24 hr. broth culture of the test organism.

In the intermediate class (nos. 8 and 9 in the Table) there may or may not be some degree of inhibition of Bact. coli as well as of Staph. aureus. The titres in col. 6 indicate merely the order of magnitude of the antibacterial effect.

From these screening tests it should be possible, with the aid of the Table, to conclude that the unknown inhibitor is not identical with any of the fourteen listed, that it is one or other of those in the list or that more than one active substance is present.

(4) In those cases where the screening tests narrow the possible identity to two or more of the substances given, certain simple chemical tests (column 3 of the Table) will distinguish between the possibilities. These tests, referred to by letter, are as follows: 

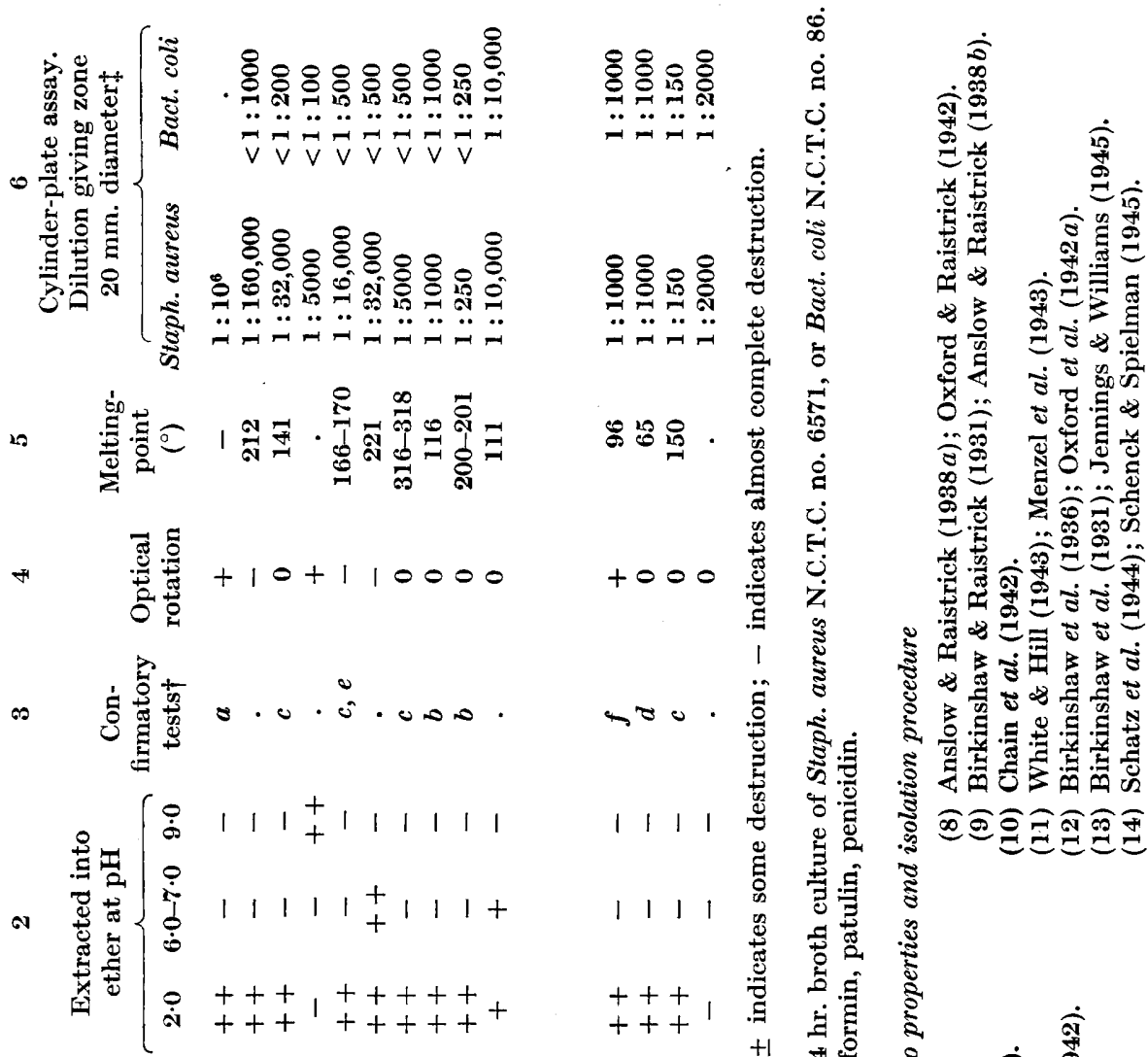

青寻 है

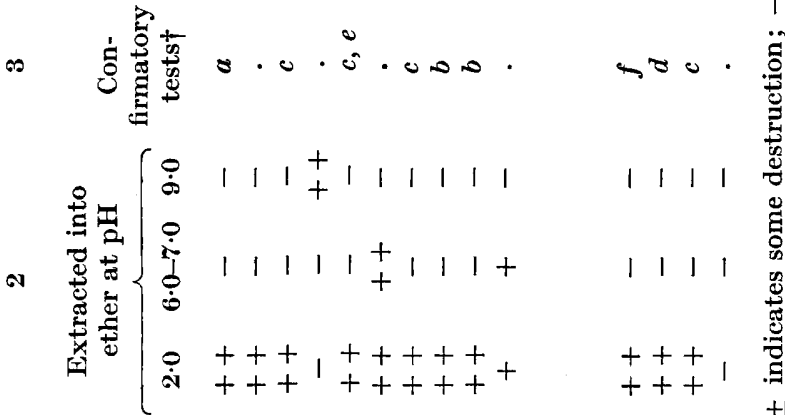

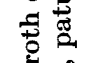

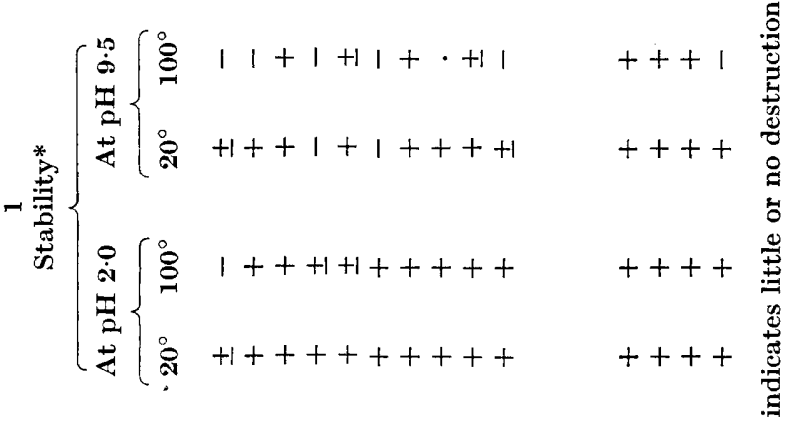

म ํㅗㄹ

:
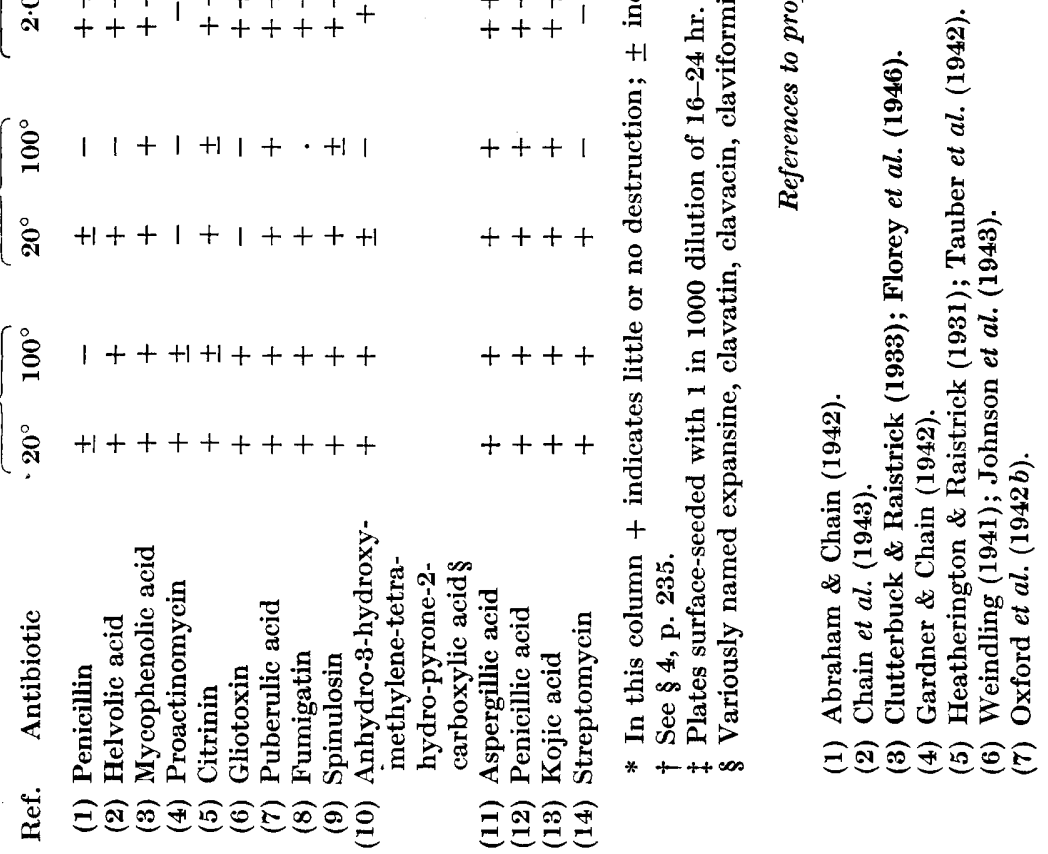

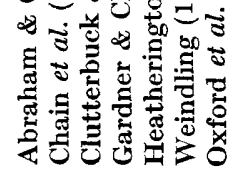

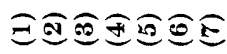

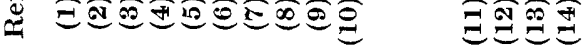


(a) The activity of the culture medium is measured after incubation in the presence and absence of penicillinase (e.g. Duthie, 1944). Destruction of the activity indicates penicillin.

(b) Fumigatin and spinulosin in the concentrations which can be detected by the cylinder-plate method give deep purple solutions. In mould cultures, however, the substances may by reduction give a paler brownish colour; on shaking in air the purple colour is restored. The purple colour is also reversibly discharged in acid solution.

(c) A drop of dilute ferric chloride solution is added to the culture medium at neutral or faintly acid $\mathrm{pH}$; a red colour indicates kojic acid; a red-brown colour indicates puberulic or puberulonic acids; a blue-violet colour indicates mycophenolic acid; a brown precipitate, soluble in excess of $\mathrm{FeCl}_{3}$ solution, indicates citrinin.

(d) 2-3 volumes of strong ammonia are added. A red colour suggests penicillic acid.

(e) On acidification, a bright yellow colour which may or may not be accompanied by a yellow precipitate, indicates citrinin.

(f) Aspergillic acid is volatile in steam.

The next stage is to confirm the tentative identification. Some tests (e.g. the penicillinase test for penicillin) have a high degree of specificity, but in other cases it may be necessary to isolate the inhibitor and apply the usual chemical criteria of identity-mixed melting-point, etc. The colour tests are suggestive, not specific; taken in conjunction with other tests they may be helpful. The presence of pigment in the medium or a low concentration of the antibiotic may make the tests of value only after some purification.

The papers cited in the Table provide further tests or isolation procedures for the antibiotics listed.

One of us (F. J. P.) is indebted to the Agricultural Research Council for a personal grant. Our thanks are due to Professor H. Raistrick for samples of spinulosin and puberulic acid, and to Dr P. W. Brian for a sample of gliotoxin; and to Miss Jean Stewart for technical assistance.

\section{REFERENCES}

Abraham, E. P. \& Chain, E. (1942). Purification and some physical and chemical properties of penicillin. Brit. J. exp. Path. 23, 103.

Anslow, W. K. \& Raistrick, H. (1938 a). Fumigatin (3-hydroxy-4-methoxy-2:5toluquinone) and spinulosin (3:6 dihydroxy-4-methoxy-2:5-toluquinone), metabolic products respectively of Aspergillus fumigatus Fresenius and Penicillium spinulosum Thom. Biochem. J. 32, 687.

Anslow, W. K. \& Raistrick, H. (1938 b). Spinulosin (3:6-dihydroxy-4-methoxy-2-5toluquinone) a metabolic product of a strain of Aspergillus fumigatus Fresenius. Biochem. J. 32, 2288.

Birkinshaw, J. H. \& Raistrick, H. (1931). On a new methoxy-dihydroxy-toluquinone produced from glucose by a species of Penicillium of the $P$. spinulosin series. Philos. Trans. 220, 245.

Birkinshaw, J. H., Charles, J. H. V., Lilly, C. H. \& Raistrick, H. (1931). Kojic acid (5-hydroxy-2-hydroxymethyl- $\gamma$-pyrone). Philos. Trans. B, 220, 127. 
Birkinshaw, J. H., Oxford, A. E. \& Raistrick, H. (1936). Penicillic acid, a metabolic product of Penicillium puberulum Bainier, and P. cyclopium Westling. Biochem. J. 30, 394.

Chain, E., Florey, H. W. \& Jennings, M. A. (1942). An antibacterial substance produced by Penicillium claviforme. Brit. J. exp. Path. 23, 202.

Chain, E., Florey, H. W., Jennings, M. A. \& Williams, T. I. (1943). Helvolic acid, an antibiotic produced by Aspergillus fumigatus, Mut. Helvola. Yuill. Brit. J. exp. Path. 24, 108.

Clutterbuck, P. W. \& Raistrick, H. (1933). The molecular constitution of the metabolic products of Penicillium brevi-compactum Dierckx and related species. Biochem. J. 27, 654.

Duthie, E. S. (1944). The production of penicillinase by organisms of the subtilis group. Brit. J. exp. Path. 25, 96.

Eisman, P. C., Marsh, W. S. \& MAyer, R. L. (1946). Differentiation of antibiotics by resistant strains. Science, $103,673$.

Florey, H. W., Gilliver, K., Jennings, M. A. \& Sanders, A. G. (1946). Mycophenolic acid, an antibiotic from Penicillium brevi-compactum Dierckx. Lancet, no. 250, p. 46.

Furtado, A. Da R. (1944). Pesquisa de atividade antibacteriana com 180 amostras de Aspergillus Micheli, 1729. Mem. Inst. Osw. Cruz, 61, 2, 205.

Gardner, A. D. \& Chain, E. (1942). Proactinomycin: a 'bacteriostatic' produced by a species of Proactinomyces. Brit. J. exp. Path. 23, 123.

Heatherington, A. C. \& Raistrick, H. (1931). On the production and chemical constitution of a new yellow colouring matter, citrinin, produced from glucose by Penicillium citrinum Thom. Philos. Trans. B, 220, 269.

Heatley, N. G. (1944). A method for the assay of penicillin. Biochem. J. 38, 61 .

Jennings, M. A. \& Williams, T. I. (1945). Production of kojic acid by Aspergillus effusus Tiraboschi. Nature, Lond., 155, 302.

Johnson, J. R., Bruce, W. F. \& Dutcher, J. D. (1943). Gliotoxin, the antibiotic principle of Gliocladium fimbriatum. I. Production, physical and biological properties. J. Amer. chem. Soc. 65, 2005.

Menzel, A. E. O., Wintersteiner, O. \& Rake, G. (1943). Note on antibiotic substances elaborated by an Aspergillus flavus strain and by an unclassified mould. J. Bact. 46, 109.

Oxford, A. E. \& Raistrick, H. (1942). Antibacterial substances from moulds. Part IV. Spinulosin and fumigatin, metabolic products of Penicillium spinulosin Thom and Aspergillus fumigatus Fresenius. Chem. Ind. 20, 128.

Oxford, A. E., Raistrick, H. \& Smith, G. (1942a). Antibacterial substances from moulds. Part II. Penicillic acid, a metabolic product of Penicillium puberulum Bainier and Penicillium cyclopium Westling. Chem. Ind. 20, 22.

Oxford, A. E., Raistrick, H. \& Smith, G. (1942b). Antibacterial substances from moulds. Part VI. Puberulic acid, $\mathrm{C}_{8} \mathrm{H}_{6} \mathrm{O}_{6}$, and Puberulonic acid, $\mathrm{C}_{8} \mathrm{H}_{4} \mathrm{O}_{6}$, metabolic products of a number of species of Penicillium. Chem. Ind. 20, 485.

Robiins, W. J., Hervey, A., Davidson, R. W., MA, R. \& Robbins, W. C. (1945). A survey of some wood destroying and other fungi for antibacterial activity. Bull. Torrey bot. Cl. 72, 165.

Schatz, A., Bugre, E. \& Waksman, S. A. (1944). Streptomycin, a substance exhibiting antibiotic activity against Gram-positive and Gram-negative bacteria. Proc. Soc. exp. Biol., N.Y., 55, 66.

Schenck, J. R. \& Spielman, M. A. (1945). The formation of maltol by the degradation of streptomycin. J. Amer. chem. Soc. 67, 2276.

Stansly, P. G. (1946). The presumptive identification of antibiotics. Science, $103,402$.

Tauber, H., LAufer, S. \& Goll, M. (1942). A colour test for citrinin and a method for its preparation. J. Amer. chem. Soc. 64, 2228. 
Weindling, R. (1941). Experimental configuration of the mould toxin of Gliocladium and Trichoderma. Phytopathology, 31, 991.

White, E. C. \& Hrll, J. H. (1943). Studies on antibacterial products formed by moulds. I. Aspergillic acid, a product of a strain of Aspergillus flavus. J. Bact. 45, 433 .

Wiedling, S. (1944). The production of antibiotics by Penicillium species. Bot. Notiser, p. 433.

WrLKINS, W. H. (1946). Investigation into the production of bacteriostatic substances by fungi. Preliminary examination of the fifth 100 species, all Basidiomycetes, mostly of the wood-destroying type. Brit. J. exp. Path. 27, 140.

Wilkins, W. H. \& Harris, G. C. M. (1942). Investigation into the production of bacteriostatic substances by fungi. I. Preliminary examination of 100 fungal species. Brit. J. exp. Path. 23, 166.

Wilkins, W. H. \& HaRris, G. C. M. (1943). Investigation into the production of bacteriostatic substances by fungi. Preliminary examination of the second 100 fungal species. Brit. J. exp. Path. 24, 141.

Wilkins, W. H. \& Harris, G. C. M. (1944a). Investigation into the production of bacteriostatic substances by fungi. Preliminary examination of the third 100 fungi, with special reference to strain variation among species of Aspergilli. Trans. Brit. mycol. Soc. 27, 113.

Wilkins, W. H. \& Harris, G. C. M. (1944,b). Investigation into the production of bacteriostatic substances by fungi. Preliminary examination of a fourth 100 fungal species. all Penicillia. Brit. J. exp. Path. 25, 135.

Wilkins, W. H. \& Harris, G. C. M. (1944 $c$ ). Investigation into the production of bacteriostatic substances by fungi. Examination of the larger Basidiomycetes. Ann. appl. Biol. 31, 261.

(Received 26 November 1946) 